\title{
MILK PRODUCTION, FEED CONVERSION RATE AND REPRODUCTION OF ZARAIBI GOAT IN RESPONSE TO BACTERIAL FEED ADDITIVE DURING LATE PREGNANCY AND LACTATION
}

\author{
M.E. ${ }^{1}$ Ahmed, E. I. Shehata ${ }^{1}$, F.F. Abou Ammou ${ }^{1}$, A.M. Abdel-Gowad ${ }^{1}$ \\ and K.M. Aiad ${ }^{2}$
}

1. Sheep and Goat Research Department, Animal Production Research Institute (APRI), Agricultural Research Center (ARC), Giza, Egypt, 2. Milk Technology Department, APRI, ARC, Giza, Egypt

\section{SUMMARY}

This work was carried out on Zaraibi does to investigate the effect of using commercial microbial supplement (Lacture) on milk production, feed conversion efficiency and some blood constituents as well as reproductive parameters such as still birth, litter size, kidding rate and kilograms of kids produced per doe per year in addition to performance of the offspring. Twenty one pregnant does were divided into three equal groups (G1, G2 and G3) and fed according to NRC allowances, where diets contained 0,1 and $2 g$ Lacture / head/ day, respectively.

The data indicated that daily milk yield during suckling period was increased (1.341 kg., $1.593 \mathrm{~kg}$. and $1.669 \mathrm{~kg}$.) with increasing the level of Lacture (0, 1 and 2 $\mathrm{g} / \mathrm{head} / \mathrm{d}$ ) in the three groups $\mathrm{G1}, \mathrm{G} 2$ and $\mathrm{G} 3$, respectively. Moreover, average milk yield during lactation period was improved by $7.06 \%$ and $13.79 \%$ in G2 and G3 groups, respectively, compared with the control, differences were found to be significant during either experimental periods. The effect of treatment was positive on milk composition, especially milk protein and lactose, however, no significant effects of Lacture were observed on milk quality. The feed utilization efficiency (based on DM and CP) was better in G2 and G3 groups (over 10\%) compared with G1 group.

Litter size ranged from 1.86 to 2.14 with no-significant differences among treatments. Daily body gain of kids was significantly improved in G2 (105.2 g) and G3 groups (108.5 g) by $11.91 \%$ and $15.43 \%$, respectively compared with that of G1 group (94.0 g).

The mortality rate of kids was $7.1 \%$ in $G 2$ and 0.00 in $G 3$ vs. $13.3 \%$ in the control group. Thus, output measured as kilograms of kids produced per doe per year improved significantly due to Lacture supplementation. Accordingly, the economic efficiency was higher due to using Lacture at levels 1 and $2 \mathrm{~g} /$ head/day compared with the control one $(0 \mathrm{~g})$.

Keywords: Zaraibi goats, Lacture yeast, milk production, kids performance, feed efficiency, mortality rate, kilograms produced per doe

\section{INTRODUCTION}

High milk yield and prolificacy (twining rate) of Zaraibi goat require attention while preparing their ration in terms of amino acids, enzymes, vitamins and other

Issued by The Egyptian Society of Animal Production 
feed requirements which are important for does, especially during phases of reproductive stress such as late pregnancy and suckling..

Yeasts are known as rich sources of vitamins, enzymes, nutrients and other important cofactors that make them attractive as a basic nutrient (Dawson, 1992). Yeast products have been shown to modify rumen fermentation (Wiedmeier et al., 1987 and Harrison et al., 1988), to stimulate the number and growth of rumen bacteria (Dawson et al., 1990 and Erasmus et al., 1992) and to increase rate of feed digestion in the rumen environment which is reflected on the productive performance of farm animals (Higgibotham et al., 1994, Besong et al., 1996, Putnam et al., 1997, El-Badawi et al., 1998, El-Ashry et al., 2002 and Abou'l Ella, 2007).

Addition of yeast culture, as growth promoter, to the diets resulted in increasing rumen $\mathrm{pH}$, total bacteria and protozoa culture count, total volatile fatty acids, total $\mathrm{N}$ and microbial protein with decreasing ammonia- $\mathrm{N}$ concentration and improving digestion of cellulose and DM disappearance (Kumar et al., 1994). Therefore, the use of yeast cultures as a dietary supplement for dairy animals for many years, is thought to; 1- improve rumen function and hence, milk production and feed efficiency by stimulating growth of rumen bacteria, particularly cellulotic species and 2- improve fiber digestibility (Harrison et al., 1988). Thus, much attention has been focused recently on the use of supplemented yeast to improve animal performance. Allam et al. (2001), El-Ashry et al. (2001), Kholif and Khorshed (2006) and Abou'l Ella (2007) reported that addition of yeast in the diet of cows, buffaloes and sheep were beneficial in improving production of milk, $4 \%$ fat corrected milk (FCM), milk fat and milk composition. However, production responses to yeast supplementation vary with species, diet, yeast level or preparation type (laboratory or commercial) and production stage (Newbold et al., 1995, Wohlt et al., 1998 and El-Ashry et al., 2001)

Increasing milk yield for lactating animals, especially Zaraibi goat, is an important factor for the production of robust kids at weaning. Therefore, the present study was carried out to investigate the effect of a commercial microbial supplement (Lacture) on milk yield, milk composition, some blood parameters in addition to the performance of offspring of lactating does.

\section{MATERIALS AND METHODS}

This study was conducted at El-Serw Experimental Research Station belongs to Animal Production Research Institute, Agricultural Research Center, Ministry of Agriculture, Egypt.

Twenty one Zaraibi does at the last 2 months of pregnancy, of $50.4 \mathrm{~kg}$ average live body weight, were allotted into three groups, 7 does each. Animals were weighed at the beginning of the experiment and biweekly thereafter. Zaraibi does received three feeding treatments in group feeding. Zaraibi does in groups G1, G2 and G3 received a daily feed supplement of $0 \mathrm{~g}$., $1 \mathrm{~g}$. and $2 \mathrm{~g}$. Lacture /head, respectively. Feed additive (Lacture) was mixed with approximately $10 \mathrm{~g}$ of ground concentrate and spread daily as powder over the concentrate feed mixture as reported by Chiquette et al. (1993).

Amounts of concentrate and roughage fed were based on Feed Allowance of NRC (1981). The concentrate feed mixture (CFM) and roughage (berseem hay and bean straw) were offered at 50:50 ratio. The CFM was consisted of 26\% undecorticated cottonseed meal, $38 \%$ yellow corn, $20 \%$ wheat bran, $7 \%$ rice bran, $5 \%$ molasses, 
$2.5 \%$ limestone, $1 \%$ common salt and $0.5 \%$ mineral mixture. Samples of feed were analyzed according to the procedures of A.O.A.C (1988). The chemical composition of feed stuffs consumed by Zaraibi does is shown in Table (1). Water was available all times. Diets were offered twice daily at 8.00 am and $3.00 \mathrm{pm}$.

Table 1. Chemical composition of feed stuffs consumed by dairy Zaraibi goat

\begin{tabular}{lccccccc}
\hline \multirow{2}{*}{ Feed } & \multirow{2}{*}{ DM } & \multicolumn{6}{c}{ Chemical composition } \\
\cline { 3 - 8 } & & OM & CF & CP & EE & NFE & Ash \\
\hline Concentrate feed mixture & 91.3 & 93.2 & 16.3 & 14.9 & 3.3 & 58.7 & 6.8 \\
Berseem hay & 88.5 & 87.50 & 30.3 & 11.2 & 2.3 & 43.7 & 12.5 \\
Bean straw & 88.9 & 86.5 & 38.0 & 5.3 & 1.3 & 41.8 & 13.5 \\
\hline
\end{tabular}

DM: Dry matter, OM: Organic matter; CF: Crude fiber; CP: Crude protein; EE: Ether extract and NFE: Nitrogen free extract.

Milk yield was recorded daily for each doe. Representative milk samples (about $0.5 \%$ of total milk produced) were taken monthly for each doe at both milkings. Samples were composed and analyzed for chemical composition of total solids, fat, protein and ash as well as $\mathrm{pH}$ and acidity (Ling, 1963), while lactose content was assessed as described by Baranett and Abdel-Tawab (1957).

Changes of live body weight were recorded individually for the does and their born kids every two weeks. Litter size (fetus/doe), kidding rate (litter size x100) were calculated. Economic efficiency was also calculated, as total output/ total input according to the local prices at the year 2008 (where 1 ton of BH costs $500 \mathrm{LE}, 1$ ton of BS costs $250 \mathrm{LE}, 1$ ton of CFM costs $1000 \mathrm{LE}$, and yeast Lacture cost L.E. 20 per $\mathrm{kg}$, while selling prices of $1 \mathrm{~kg}$ live body weight of kid was $19 \mathrm{LE}$ and $1 \mathrm{~kg}$ goat's milk was 3.25 LE).

LE).

Blood samples were collected through the jugular vein just before feeding ( 0 time) once at the end of the experiment from 5 does of each group. Whole blood was immediately used for hematological estimation. Another blood sample was centrifuged at $4000 \mathrm{rpm}$ for 20 minutes, separated serum were used for enzymes determination, while the remained part was frozen at $-20{ }^{0} \mathrm{C}$ until other biochemical analyses. Commercial kits were used for all blood measures, except globulin which was calculated by differences.

Data were statistically analyzed by the least squares method described by Likelihood program of SAS (1994). Differences among means were determined by Duncan's New Multiple Range Test (Duncan, 1955).

\section{RESULTS AND DISCUSSION}

Average daily feed intake during pregnancy, suckling and lactation periods) are presented in Table (2). The daily feed intake was not affected by the experimental treatments, whereas the major differences was noticed during suckling $(1697 \mathrm{~g} / \mathrm{h}$, $1783 \mathrm{~g} / \mathrm{h}$ and $1842 \mathrm{~g} / \mathrm{h}$ ) and lactation periods (1467 g DM, $1486 \mathrm{~g} \mathrm{DM}$ and $1555 \mathrm{~g}$ DM) for groups G1, G2 and G3, respectively. Similar results were observed by Swarts et al. (1994), Soder and Holden (1999), El- Ashry et al. (2001) and Kholif and Khorshed (2006). However, Wohlt et al. (1991), Erasmus et al. (1992), Olson et al. (1994), Yousef et al. (1996) and Putnam et al. (1997) reported a significant 
improvement in dry matter intake when yeast culture was given to lactating animals. Also, Abou'l Ella (2007) found that total dry matter intake was significantly higher with addition of dried yeast to lactating ewe's rations. The enhanced intake is most likely referred to improvement of the rate of breakdown of feed stuffs in the rumen (Abou'l Ella, 2007).

Table 2. Average daily dry matter (DM) intake* by Zaraibi does during different experimental periods (gestation, suckling and lactation)

\begin{tabular}{lccc}
\hline & & Groups & \\
\cline { 2 - 3 } Item & G1 & G2 & G3 \\
\hline Daily DM intake (g/d) during gestation & & \\
From CFM & 794 & 815 & 805 \\
From BH & 396 & 405 & 409 \\
From BS & 398 & 413 & 415 \\
Total DM intake & 1588 & 1633 & 1629 \\
DM intake, \% of BW & 2.97 & 2.95 & 3.01 \\
Roughage/ concentrate ratio (R/C) & $50: 50$ & $50: 50$ & $51: 49$ \\
Daily DM intake (g/d) during suckling period & & \\
From CFM & 863 & 900 & 921 \\
From BH & 420 & 445 & 466 \\
From BS & 414 & 438 & 455 \\
Total DM intake & 1697 & 1783 & 1842 \\
DM intake, \% of BW & 3.98 & 4.19 & 4.38 \\
R/C ratio & $49: 51$ & $50: 50$ & $50: 50$ \\
Daily DM intake (g/h) during lactation period & & \\
From CFM & 728 & 750 & 800 \\
From BH & 360 & 363 & 375 \\
From BS & 379 & 373 & 380 \\
Total DM intake & 1467 & 1486 & 1555 \\
DM intake, \% of BW & 3.58 & 3.53 & 3.69 \\
R/C ratio & $50: 50$ & $50: 50$ & $49: 51$ \\
\hline
\end{tabular}

* Group feeding; CFM: Concentrate Feed Mixture; BH: Berseem hay; BS: Bean straw; DM: Dry matter; BW; Body weight.

Milk yield during suckling (early lactation) and lactation period are presented in Table (3). Daily milk yield reached the peak at the $4^{\text {th }}$ week of lactation in all groups (Figure 1). Milk yield during suckling period were significantly higher in G2 (143.1 $\mathrm{kg} / \mathrm{h}$ or $1.593 \mathrm{~kg} / \mathrm{h} / \mathrm{d})$ and $\mathrm{G} 3(148.7 \mathrm{~kg} / \mathrm{h}$ or $1.650 \mathrm{~kg} / \mathrm{h} / \mathrm{d})$ compared with that of the control group $(125.4 \mathrm{~kg} / \mathrm{h}$ or $1.401 \mathrm{~kg} / \mathrm{h} / \mathrm{d})$. However, there was no significant response to increasing Lacture yeast level from $1 \mathrm{~g}$ to $2 \mathrm{~g}$.

During lactation period, the highest milk yield $(95.79 \mathrm{~kg} / \mathrm{h}$ or $1.064 \mathrm{~kg} / \mathrm{h} / \mathrm{d})$ was recorded in G3, followed by G2 $(90.21 \mathrm{~kg} / \mathrm{h}$ or $1.001 \mathrm{~kg} / \mathrm{h} / \mathrm{d})$ while, the lowest value was detected in the control group $(83.8 \mathrm{~kg} / \mathrm{h}$ or $0.935 \mathrm{~kg} / \mathrm{h} / \mathrm{d})$ and the differences among groups were significant. Daily milk yields were improved during lactation period $(7.06 \%$ and $13.79 \%)$ and suckling period (13.70\% and $17.77 \%)$ in G2 and G3 groups, respectively compared with that in the control group. These results are in accordance with those reported by Wohlt et al. (1991), Erasmus et al. (1992), Piva et al. (1993), Yousef et al. (1996) and Putnam et al. (1997). Yields of milk were 
significantly improved by including yeast in the rations (El-Ashry et al., 2001). They reported that the higher milk yield of those animals fed yeasts supplemented ration might be attributed to its positive effect on digestibility of organic matter and its nutrients. Moreover, results probably attributed to the higher blood serum glucose and albumin concentrations of animals fed yeasts supplemented ration (Table 5) as it led to an increase in milk lactose synthesis and consequently increased milk production (Kholif and Khorshed, 2006 and Kholif and Kholif, 2008).

Table 3. Milk production of dairy Zaraibi does fed the experimental rations during suckling and lactation period

\begin{tabular}{|c|c|c|c|}
\hline \multirow[t]{2}{*}{ Item } & \multicolumn{3}{|c|}{ Groups } \\
\hline & G1 & G2 & G3 \\
\hline Suckling period: & & & \\
\hline Daily milk yield $(\mathrm{kg} / \mathrm{h} / \mathrm{d})$ & $1.40^{b} \pm 0.05$ & $1.59^{\mathrm{a}} \pm 0.04$ & $1.65^{\mathrm{a}} \pm 0.05$ \\
\hline Total milk yield (kg/h) & $125.4^{b} \pm 4.05$ & $143.1^{\mathrm{a}} \pm 3.80$ & $148.7^{\mathrm{a}} \pm 4.55$ \\
\hline \multicolumn{4}{|l|}{ Milk composition } \\
\hline Fat, $\%$ & $3.34 \pm 0.07$ & $3.43 \pm 0.06$ & $3.48 \pm 0.04$ \\
\hline Protein, $\%$ & $2.97^{\mathrm{b}} \pm 0.02$ & $3.19^{\mathrm{a}} \pm 0.02$ & $3.21^{\mathrm{a}} \pm 0.02$ \\
\hline Lactose, $\%$ & $4.62^{b} \pm 0.01$ & $4.79^{\mathrm{a}} \pm 0.00$ & $4.87^{\mathrm{a}} \pm 0.02$ \\
\hline Total Solids, $\%$ & $11.65 \pm 0.08$ & $12.14 \pm 0.07$ & $12.20 \pm 0.05$ \\
\hline Solids non fat (SNF), \% & $8.30 \pm 0.02$ & $8.71 \pm 0.02$ & $8.81 \pm 0.03$ \\
\hline Ash, \% & $0.72 \pm 0.01$ & $0.73 \pm 0.00$ & $0.73 \pm 0.00$ \\
\hline Somatic cell count's $(\mathrm{SCC}) \times 10^{3}$ & $546 \pm 19$ & $539 \pm 21$ & $516 \pm 17$ \\
\hline $\mathrm{pH}$ value & $6.63 \pm 0.01$ & $6.65 \pm 0.01$ & $6.66 \pm 0.00$ \\
\hline Acidity, \% & $0.163 \pm 0.001$ & $0.165 \pm 0.001$ & $0.167 \pm 0.001$ \\
\hline \multicolumn{4}{|l|}{ Lactation period: } \\
\hline Daily milk yield $(\mathrm{kg} / \mathrm{h} / \mathrm{d})$ & $0.93^{\mathrm{b}} \pm 0.04$ & $1.00^{\mathrm{ab}} \pm 0.03$ & $1.06^{\mathrm{a}} \pm 0.02$ \\
\hline Total milk yield $(\mathrm{kg} / \mathrm{h})$ & $83.80^{b} \pm 3.81$ & $90.21^{\mathrm{ab}} \pm 2.57$ & $95.79^{\mathrm{a}} \pm 2.11$ \\
\hline \multicolumn{4}{|l|}{ Milk composition } \\
\hline Fat, $\%$ & $4.05 \pm 0.05$ & $4.18 \pm 0.06$ & $4.23 \pm 0.05$ \\
\hline Protein, $\%$ & $3.00^{\mathrm{b}} \pm 0.02$ & $3.21^{\mathrm{a}} \pm 0.02$ & $3.24^{\mathrm{a}} \pm 0.02$ \\
\hline Lactose, $\%$ & $4.63 \pm 0.02$ & $4.81 \pm 0.03$ & $4.89 \pm 0.03$ \\
\hline Total Solids, \% & $12.41 \pm 0.11$ & $12.95 \pm 0.06$ & $13.01 \pm 0.05$ \\
\hline $\mathrm{SNF}, \%$ & $8.36 \pm 0.08$ & $8.77 \pm 0.01$ & $8.87 \pm 0.02$ \\
\hline Ash, $\%$ & $0.73 \pm 0.01$ & $0.75 \pm 0.01$ & $0.74 \pm 0.01$ \\
\hline Somatic cell count's $(\mathrm{SCC}) \times 10^{3}$ & $425 \pm 16$ & $411 \pm 29$ & $407 \pm 25$ \\
\hline $\mathrm{pH}$ value & $6.64 \pm 0.01$ & $6.67 \pm 0.01$ & $6.68 \pm 0.01$ \\
\hline Acidity $\%$ & $0.16 \pm 0.001$ & $0.16 \pm 0.001$ & $0.16 \pm 0.001$ \\
\hline
\end{tabular}

Means in the same row with different superscripts differ significantly at $\mathrm{P}<0.05$

In lactating ewes, Abou'l Ella (2007) stated that the relative improvement in milk production as a result of using yeast in sheep ration could be attributed to the fact that yeast may act as a source of B-vitamins, which may occasionally be beneficial, in addition to that the flow of microbial protein from the rumen will increase with addition of yeast to the diet.

Milk protein content was higher in G2 and G3 than G1. This result is in accordance with those reported on lactating animals fed diets supplemented with yeast culture (Kumar et al., 1992, Yousef et al., 1996, Putnam et al., 1997 and El- 
Ashry et al., 2001). Skorko-Sajko et al. (1993) reported that the increased flow of lysine and methionine observed by Erasmus (1991) might help to explain the increase in milk and milk protein yield. In addition, the increase in milk protein yield by yeast culture supplementation may be due to stimulation of rumen microbes, that cause alteration in microbial protein synthesis and increased protein passage then protein yield (El- Ashry et al., 2001).

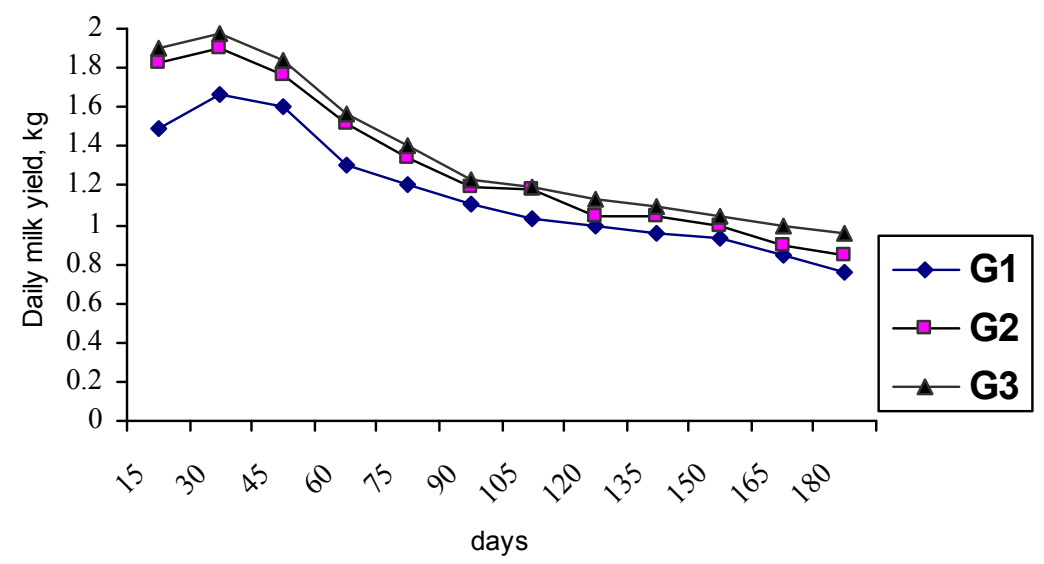

Figure 1. Effect of the experimental treatments on daily milk yield of Zaraibi goat

Milk fat content in G2 and G3 groups were insignificantly higher by $3.89 \%$ and $2.69 \%$ than those in G1. That is in accordance with those reported by Soder and Holden (1999) and El-Ashry et al. (2001). However, Abd-El-Ghani et al. (1995) and Yousef et al. (1996) found that lactating animals fed yeast culture had significant increase in milk fat content. In lactating ewes, Abou'l Ella (2007) observed that milk fat percentage was $7.12 \%$ to $7.30 \%$ higher as a result of using yeast, thus milk fat yield was significantly higher from $46.3 \mathrm{~g} / \mathrm{h} / \mathrm{d}$ to $52.6 \mathrm{~g} / \mathrm{h} / \mathrm{d}$ with the same addition.

Milk lactose content was higher $(\mathrm{P}<0.05)$ in $\mathrm{G} 2$ and $\mathrm{G} 3$ compared with $\mathrm{G} 1$ group as shown in Table (3). Similar results were observed by El- Ashry et al. (2001) and Abou'l Ella (2007) on lactating buffaloes and ewe's. In another study, milk lactose content was higher as a result of addition of selenized yeast and this may be attributed to the positive effect of treatment on the metabolic process in the mammary gland which led to increase milk lactose synthesis (Kholif and Khorshed, 2006).

The total solids, SNF, ash, $\mathrm{pH}$ and acidity showed similar trends to that of fat content with no significant differences among groups. These results are in accordance with those obtained by Erasmus et al. (1992), Piva et al. (1993), Soder and Holden (1999), El-Ashry et al. (2001) and Kholif and Khorshed (2006). Abou'l Ella (2007) observed that total solids yield was significantly improved from $131.6 \mathrm{~g} / \mathrm{h} / \mathrm{d}$ to 147.1 $\mathrm{g} / \mathrm{h} / \mathrm{d}$ as a result of using yeast in lactating ewe's ration, whereas total solids percentage was not affected by the treatment. 
Data in Table (3) showed that there were no significant differences in somatic cells count (SCC) among different treatments during the suckling and lactation periods. This suggests that addition of Lacture yeast to the rations did not have negative effects on goat's general health given the association of SCC with microbial infection in animals. That seems to be consistent with Pernthaner et al. (1991) and Shehata et al. (2004).

Data of feed utilization efficiency of the experimental goat are summarized in Table (4). The obtained results indicated that feed conversion calculated as dry matter intake and crude protein intake/milk yield were better in G2 and G3 groups compared with the control (G1), being $10.49 \%$ and $11.11 \%$, higher than the control, respectively, based on CP. The positive effect (based on DM and CP) was observed also by El-Ashry et al. (2002). Kholif and Khorshed (2006) reported that feed efficiency was significantly better with animals fed yeast supplemented rations followed by selenized yeast supplemented ration and then the control. In sheep, Abou'l Ella (2007) observed that feed efficiency calculated as fat corrected milk $(\mathrm{FCM})$ /dry matter intake was $11.52 \%$ higher in lactating ewes fed yeast supplemented rations compared with the control.

Table 4. Feed utilization efficiency by Zaraibi does as affected by the experimental treatments

\begin{tabular}{lccc}
\hline \multicolumn{1}{c}{ Item } & \multicolumn{3}{c}{ Groups } \\
\cline { 2 - 4 } & $\mathrm{G} 1$ & $\mathrm{G} 2$ & $\mathrm{G} 3$ \\
\hline No. of does & 7 & 7 & 7 \\
Av. body weight, kg & 41.21 & 42.31 & 42.11 \\
Metabolic body size, W $\mathrm{W}^{0.75}$ & 16.26 & 16.59 & 16.53 \\
Av. feed intake during milk production period (suckling and lactation) & \\
From CFM, g/h/d & 796 & 825 & 861 \\
From BH, g/h/d & 390 & 404 & 421 \\
From BS, g/h/d & 397 & 406 & 418 \\
Total DM intake g/h/d & 1583 & 1635 & 1700 \\
DM intake, g/kg W ${ }^{0.75}$ & 97.0 & 99.0 & 103.0 \\
DM intake, \% BW & 3.80 & 3.90 & 4.04 \\
R/C ratio & $50: 50$ & $50: 50$ & $49: 51$ \\
CP intake, g/h/d & 184 & 189 & 197 \\
Av. daily milk yield, g/h/d & $1161^{\mathrm{b}} \pm 41$ & $1297^{\mathrm{a}} \pm 25$ & $1358^{\mathrm{a}} \pm 32$ \\
Feed utilization efficiency: & & & \\
kg DM/kg milk & 1.39 & 1.26 & 1.24 \\
$\mathrm{~kg} \mathrm{CP/} \mathrm{kg} \mathrm{milk}$ & 0.162 & 0.145 & 0.144
\end{tabular}

Means in the same row with different superscripts differ significantly at $\mathrm{P}<0.05$.

CFM: Concentrate Feed Mixture; BH: Berseem hay; BS: Bean straw; DM: Dry matter; BW; Body weight; $\mathrm{R} / \mathrm{C}$ : Roughage to concentrate ratio.

The data in Table (5) indicated that yeast supplemented groups had significantly higher hemoglobin (Hb), red blood cells (RBC's), mean cell hemoglobin concentration (MCHC), serum glucose and albumin than the control. The same trend was observed also on serum protein, globulin, urea-N and cholesterol. Similar results were observed by Yousef et al. (1996) and Kholif and Khorshed (2006) on lactating animals. El- Ashry et al. (2001) reported that serum total protein, albumin, urea-N, 
glucose and cholesterol content were significantly higher as a result of using some yeast types in dairy animals rations. In lactating ewes, concentration of plasma total protein, albumin, globulin and urea were higher with yeast supplemented groups where differences were significant for serum albumin only. The obtained results in Table (5) indicated that serum transaminases (AST and ALT) activities were not significantly affected by the treatments. Also, serum alkaline phosphatase (ALP) activity recorded the highest value $(105.11 \mathrm{u} / \mathrm{l})$ in $\mathrm{G} 1$ and the lowest value $(97.39 \mathrm{u} / \mathrm{l})$ in G3 group. However, El-Ashry et al. (2001) reported that transaminases (AST and ALT) activities in blood serum were unchanged by adding dietary yeast culture, but serum ALP activity was significantly lower with using some yeast types in the diets. The present blood parameters of supplemented treated groups may indicate the beneficial effect of the supplements on doe's metabolism.

Table 5. Blood profile of Zaraibi does as affected by the experimental treatments

\begin{tabular}{|c|c|c|c|}
\hline \multirow{2}{*}{ Items } & \multicolumn{3}{|c|}{ Groups } \\
\hline & G1 & $\mathrm{G} 2$ & G3 \\
\hline Hemoglobin, g/dl & $11.53^{\mathrm{b}} \pm 0.29$ & $13.37^{\mathrm{a}} \pm 0.34$ & $13.75^{\mathrm{a}} \pm 0.43$ \\
\hline Hematocrit, $\%$ & $32.27 \pm 0.89$ & $34.40 \pm 0.70$ & $35.00 \pm 1.04$ \\
\hline Red blood cells $\times 10^{6} / \mathrm{ul}$ & $12.70^{\mathrm{b}} \pm 0.42$ & $14.40^{\mathrm{a}} \pm 0.45$ & $14.90^{\mathrm{a}} \pm 0.32$ \\
\hline $\begin{array}{l}\text { Mean cell hemoglobin } \\
\text { concentration , \% }\end{array}$ & $35.70^{\mathrm{b}} \pm 0.37$ & $38.90^{\mathrm{ab}} \pm 0.20$ & $39.30^{\mathrm{a}} \pm 0.18$ \\
\hline Glucose, $\mathrm{mg} / \mathrm{dl}$ & $65.33^{\mathrm{b}} \pm 0.88$ & $70.00^{\mathrm{a}} \pm 0.58$ & $71.67^{\mathrm{a}} \pm 0.88$ \\
\hline Total protein, g/dl & $6.87 \pm 0.29$ & $7.25 \pm 0.29$ & $7.43 \pm 0.52$ \\
\hline Albumin, g/dl & $3.50^{\mathrm{b}} \pm 0.15$ & $3.83^{\mathrm{a}} \pm 0.15$ & $3.87^{\mathrm{a}} \pm 0.09$ \\
\hline Globulin, g/dl & $3.37 \pm 0.15$ & $3.42 \pm 0.16$ & $3.57 \pm 0.43$ \\
\hline Urea- $\mathrm{N}, \mathrm{mg} / \mathrm{dl}$ & $15.53 \pm 0.43$ & $17.13 \pm 0.52$ & $17.43 \pm 0.46$ \\
\hline $\mathrm{AST}, \mathrm{u} / 1$ & $69.00 \pm 2.65$ & $70.33 \pm 1.76$ & $73.00 \pm 2.08$ \\
\hline $\mathrm{ALT}, \mathrm{u} / 1$ & $13.57 \pm 0.77$ & $12.60 \pm 0.78$ & $15.03 \pm 0.94$ \\
\hline ALP, $\mathrm{u} / 1$ & $105.00 \pm 4.58$ & $103 . .3 \pm 3.71$ & $98.00 \pm 3.21$ \\
\hline Cholesterol, mg/dl & $110.00 \pm 2.52$ & $115.3 \pm 5.17$ & $117.0 \pm 6.43$ \\
\hline
\end{tabular}

Table (6) presented changes in live body weight (LBW). The mean initial LBW (at 3 months of pregnancy) were approximately equal in all groups ranged from 49.5 $\mathrm{kg}$. to $51.0 \mathrm{~kg}$. The LBW of does increased to the maximum before parturition and recorded the highest values (ranged from $57.7 \mathrm{~kg}$ in G1 to $59.9 \mathrm{~kg}$ in G2) then sharply decreased (post- parturition) to the minimum at day $90^{\text {th }}$ (weaning) in all groups. Thereafter, it tended to increase again (but very slowly) in all groups during the lactation period. The same trend was observed by Shehata et al. (2007 a). Devendra (1979) recorded a decline in body weight of high milk yielding goat during the first month post-parturition. Moreover, Ahmed (1999) found that dairy Zaraibi goat fed $100 \%$ NRC had decreased LBW from $13 \%$ to $22 \%$ at day $60^{\text {th }}$ postparturition. Concerning the effect of the treatment, the obtained results indicated that LBW was not significantly affected as a result of using Lacture at level of $1 \mathrm{~g} / \mathrm{head}$ (G2) and $2 \mathrm{~g} /$ head (G3) as shown in Table (6). However, the highest values of LBW at the end of pregnancy $(59.90 \mathrm{~kg})$ and at mating $(42.5 \mathrm{~kg})$ was recorded with $\mathrm{G} 2$, but 
the lowest values were recorded with G1 $(57.7 \mathrm{~kg}$ and $41.0 \mathrm{~kg}$, respectively). Body weights during weaning were 40.1, 41.5 and 41.7 for G1, G2 and G3, respectively. Generally, body weights at day 180 post kidding (mating) were $94.25 \%, 95.72 \%$ and $96.12 \%$ higher than the weight at kidding, respectively. These data indicated some positive effects of the treatment on live body weight of Zaraibi does especially during the reproduction stress-phases (late pregnancy and suckling).

Table 6. Live body weight of Zaraibi does during late pregnancy, suckling and lactation periods

\begin{tabular}{lccc}
\hline \multicolumn{1}{c}{ Days } & \multicolumn{3}{c}{ Groups } \\
\cline { 2 - 4 } & $\mathrm{G} 1$ & $\mathrm{G} 2$ & $\mathrm{G} 3$ \\
\hline Initial weight (at 90 days of pregnancy) & $49.5 \pm 0.2$ & $51.0 \pm 0.3$ & $50.2 \pm 0.2$ \\
At 120 days of pregnancy & $52.9 \pm 0.4$ & $54.5 \pm 0.2$ & $53.6 \pm 0.3$ \\
At 150 days of pregnancy & $57.7 \pm 0.3$ & $59.9 \pm 0.2$ & $58.8 \pm 0.3$ \\
Weight at kidding & $43.5 \pm 0.2$ & $44.4 \pm 0.4$ & $43.8 \pm 0.2$ \\
Weight at 30 days post kidding & $41.7 \pm 0.3$ & $42.5 \pm 0.2$ & $42.0 \pm 0.4$ \\
Weight at 60 days post kidding & $40.5 \pm 0.4$ & $41.7 \pm 0.3$ & $41.9 \pm 0.2$ \\
Weight at 90 days post kidding & $40.1 \pm 0.1$ & $41.5 \pm 0.2$ & $41.7 \pm 0.4$ \\
(weaning) & & & \\
Weight at 120 days post kidding & $40.3 \pm 0.4$ & $41.5 \pm 0.3$ & $41.8 \pm 0.3$ \\
Weight at 150 days post kidding & $41.4 \pm 0.3$ & $42.3 \pm 0.2$ & $42.5 \pm 0.1$ \\
Weight at 180 days post kidding (mating) & $41.0 \pm 0.1$ & $42.5 \pm 0.2$ & $42.1 \pm 0.4$ \\
Weight at 180 days as \% of weight at & 94.3 & 95.7 & 96.1 \\
kidding, \% & & & \\
\hline
\end{tabular}

The productive and reproductive performance of does fed the experimental diets is summarized in Table (7). The obtained results indicated that treatment by the two levels of Lacture yeast (G2 and G3) had no adverse effect on Zaraibi does performance during late pregnancy. No abortion and still birth cases were happened in all groups. Litter size ranged from 1.86 to 2.14 without marked differences among treatments. Moreover, kidding rate were 214, 200 and 186 for groups G1, G2 and G3, respectively. However, litter size was found to be ranged from 2.31 to 2.47 in Zaraibi goat (Shehata, 2007b).

The obtained results indicated that average birth weight was higher $(2.60 \mathrm{~kg} / \mathrm{h} / \mathrm{d}$ and $2.65 \mathrm{~kg} / \mathrm{h} / \mathrm{d}$ vs. $2.35 \mathrm{~kg} / \mathrm{h} / \mathrm{d}$ ) with increasing level of Lacture yeast (G2 and G3 vs. G1, respectively). Also, the levels of Lacture $(1 \mathrm{~g} / \mathrm{h} / \mathrm{d}$ and $2 \mathrm{~g} / \mathrm{h} / \mathrm{d}) \mathrm{had}$ positive effects on weaning weight $(12.07 \mathrm{~kg} / \mathrm{h} / \mathrm{d}$ and $12.42 \mathrm{~kg} / \mathrm{h} / \mathrm{d}$ vs. $10.75 \mathrm{~kg} / \mathrm{h} / \mathrm{d}$ for $\mathrm{G} 2$ and G3 vs. G1, respectively). That was reflected on daily body gain (DBG), being $105.2 \mathrm{~g} / \mathrm{h} / \mathrm{d}$ and $108.5 \mathrm{~g} / \mathrm{h} / \mathrm{d}$ for G2 and G3 compared with $94.0 \mathrm{~g} / \mathrm{h} / \mathrm{d}$ for $\mathrm{G} 1$. The improvements in DBG, by treatments G2 and G3 were $11.91 \%$ and $15.43 \%$, respectively compared with G1 where differences were significant. Similar results were observed by El-Ashry et al. (2002) and Hanafy (2008). In other study on lactating ewes, Abou'l Ella (2007) found that average daily body gain of lambs were significantly higher $(182 \mathrm{~g} / \mathrm{h} / \mathrm{d})$ with using dry yeast in ewes rations compared with the control $(162 \mathrm{~g} / \mathrm{h} / \mathrm{d})$. This increase in daily gain of offspring may be due to the higher milk yield and its content from total solids, total protein and fat. The mortality rate of born kids was decreased $(13.3 \%, 7.1 \%$ and $0.00 \%)$ with the increasing of Lacture yeast level in groups G1, G2 and G3, respectively. Accordingly, output 
measured as kilograms kids produced per doe per year improved significantly due to the treatment by Lacture as number of kilograms at weaning were 19.90, 22.50 and $23.20 \mathrm{~g}$ for G1, G2 and G3, respectively. Generally, increasing milk yield for lactating ewes by the treatment represents an important factor for the production of robust lambs at weaning. In addition, it also have been effective in reducing incidence of scouring and mortality and stimulated live weight gain for offspring (Umberger et al., 1989 and Abou'l Ella, 2007).

Table 7. Effect of the experimental treatments on the productive and reproductive performance of dairy Zaraibi does

\begin{tabular}{lccc}
\hline \multirow{2}{*}{ Items } & \multicolumn{3}{c}{ Groups } \\
\cline { 2 - 4 } & $\mathrm{G} 1$ & $\mathrm{G} 2$ & $\mathrm{G} 3$ \\
\hline No of does & 7 & 7 & 7 \\
Born kids & 15 & 14 & 13 \\
Still birth kids, No. & - & - & - \\
Alive kids at 0 day & 15 & 14 & 13 \\
Alive kids at 90 days & 13 & 13 & 13 \\
Litter size & 2.14 & 2.0 & 1.86 \\
Kidding rate, \% & 214 & 200 & 186 \\
Average birth weight, kg & $2.35^{\mathrm{b}} \pm 0.05$ & $2.00^{\mathrm{a}} 60 \pm 0.08$ & $2.65^{\mathrm{a}} \pm 0.10$ \\
Average weaning weight, kg & $10.75^{\mathrm{b}} \pm 0.18$ & $12 .{ }^{\mathrm{a}} 07 \pm 0.14$ & $12.42^{\mathrm{a}} \pm 0.20$ \\
Total body gain, kg & $8.40^{\mathrm{b}} \pm 0.33$ & $9.47^{\mathrm{a}} \pm 0.45$ & $9.77^{\mathrm{a}} \pm 0.48$ \\
Average daily body gain, g & $94.00^{\mathrm{b}} \pm 0.17$ & $105.20^{\mathrm{a}} \pm 0.25$ & $108.50^{\mathrm{a}} \pm 0.24$ \\
Kilogram kids born /doe & $5.04 \pm 0.51$ & $5.21 \pm 0.55$ & $4.93 \pm 0.55$ \\
Kilogram kids weaned/doe & $19.90^{\mathrm{b}} \pm 2.71$ & $22.50^{\mathrm{a}} \pm 2.94$ & $23.20^{\mathrm{a}} \pm 3.08$ \\
Mortality of kids, No. & 2 & 1 & $\mathrm{zero}^{\mathrm{a}}$ \\
Mortality of kids, \% $\%$ & 13.30 & 7.10 & 0.00 \\
Economic efficiency & 2.25 & 2.42 & 2.48 \\
\hline
\end{tabular}

Means in the same row with different superscripts differ significantly at $\mathrm{P}<0.05$

Economic efficiency $($ estimated for 8 months $)=\underline{\text { milk yield } * 3.25+\mathrm{kg} \mathrm{kids} * 19}$

Feed cost $/ 240$ days.

Table 8. Effect of the experimental treatments on the performance of Zaraibi kids

\begin{tabular}{clcccc}
\hline \multicolumn{2}{c}{ Item } & No & Birth weight, kg & No. & Weaning weight, kg \\
\hline \multirow{2}{*}{ Sex } & Male & 29 & $2.61 \pm 0.06$ & 27 & $11.71 \pm 0.21$ \\
& Female & 13 & $2.35 \pm 0.06$ & 12 & $11.67 \pm 0.22$ \\
\multirow{4}{*}{ Type of } & Single & 2 & $2.75^{\mathrm{A}} \pm 0.25$ & 2 & $12.25^{\mathrm{A}} \pm 0.75$ \\
birth & Twins & 28 & $2.61^{\mathrm{A}} \pm 0.06$ & 26 & $11.93^{\mathrm{A}} \pm 0.19$ \\
& Triplets & 9 & $2.31^{\mathrm{B}} \pm 0.09$ & 8 & $11.75^{\mathrm{AB}} \pm 0.26$ \\
& Quadratic & 3 & $2.25^{\mathrm{B}} \pm 0.14$ & 3 & $10.92^{\mathrm{B}} \pm 0.08$ \\
\hline
\end{tabular}

Means in the same column with different superscripts differ significantly at $(\mathrm{P}<0.05)$

G1: $0 \mathrm{~g}$ Lacture/head/day; G2: $1 \mathrm{~g}$ Lacture/head/day; G3: $2 \mathrm{~g}$ Lacture/head/day 


\section{CONCLUSION}

It could be concluded that microbial supplement of Lacture to Zaraibi doe's rations during late pregnancy and lactation periods had a positive role in improving milk yield and its composition, especially milk protein and lactose, without any adverse effect on milk quality or general health. This improvement was reflected on born kids performance and production of robust kids at weaning and consequently reducing mortality rate for born kids. Accordingly, output measured as kilograms kids produced per doe per year was improved significantly due to the treatment. This had a good economic return on the herd of Zaraibi goats.

\section{REFERENCES}

Abd El-Ghani, A.A., M.A.A.El- Barody and O.A.O. Saad, 1995. Milk yield and composition, blood metabolites and rumen activity as affected by different levels of Saccharomyces cerevisiae plus growth medium supplementation in Egyptian buffaloes. In Proc. $5^{\text {th }}$ Sci. Conf. Animal Nutrition, 1:115. Ismailia, Dec., 1995.

Abou'l Ella A.A., 2007. Effect of dry yeast and/ or bentonite as feed additives on the productive perfermance of lactating ewes and its offsprings. Egypt. J. Nutr. and Feeds, 10:81.

Ahmed, M.E., 1999. Improving feed conversion efficiency during reproductive stress. phases. Ph.D. Thesis, Fac. Agric. Mansoura Univ.

Allam, A.M.,K.El-Shazly, B.E.A. Borhmi and M.A.Mohamed (2001): Effect of baker's yeast (Saccharomyces Cerevisiae) supplementation on digestion in sheep and milk response in dairy cows. Egypt J. Nutritional and Feeds, (special Issue): 315.

A.O.A.C., 1988. Official Methods of Analysis of the Association of Official Analytical Chemists. $12^{\text {th }}$ Ed. Washington. D.C.

Barnett, A.S. and G. Abdel-Tawab, 1957. A rapid method for determination of lactose in milk and cheese. J. Sci. Food Agric., 8:437.

Besong, S., J.A. Jackson, C.L. Hicks and R.W. Hemken, 1996. Effects of a supplemental liquid yeast product on feed intake, ruminal profiles, and yield composition, and organoleptic characteristics of milk from lactating Holstein cows. J. Dairy Sci.79:1654.

Chiquette, J., C. L. Girard, and J. J. Matte, 1993. Effect of the diet fed to growing steers and folic acid addition on digestibility and ruminal fermentation. J. Anim. Sci. 71:2793.

Dawson ,K.A. (1992). Current and future role of yeast cultures in animal production: A review of research over the last six years. In: Supplement to the proceedings of Altech $8^{\text {th }}$ Annual Symposium. 1:23.

Dawson, K.A., K.E. Newman and J.A. Boling, 1990. Effects of microbial supplements containing yeast and lactobaclilli on roughage-fed ruminal microbial activities. Anim. Sci., 63:3392.

Devendra, C., 1979. Coat production in Asian region, current status available, genetic resources and potential prospects. Indian Dairy Man., xxx:513.

Duncan, D.B.(1955) Multiple Range and Multiple F-test Biometrices, 11:1- 42. 
El -Badawi, A.Y., H.M. Gado and M.A. Tawila, 1998. Influence of dietary yeast culture on the lactation performance of goats. Arab Univ. J. Agric. Sci., Ain Shams Univ., Cairo, 6:111.

El-Ashry, M.A., Zeba A. Motagally and Y.A. Maareck, 2001. Effect of live dried baker's yeast and yeast culture on performance of growing buffalo calves. Egypt J. Nutrition and Feeds, 4 (special Issue):607.

El-Ashry, M. A., Zeba A. Motagally and Y. A. Maareck, 2002. Effect of live dried baker's yeast with or without acidification of milk and yeast culture on performance of suckling buffalo calves. Egypt. J .Nutr. and feeds, 5:31.

Erasmus L.J.(1991). The importance of duodenal amino acid profiles for dairy cows and the impact of changes in these profiles following the use of yea- $\operatorname{sacc}^{1026}$. Feed Compounder, 11.24.

Erasmus L.J., PM. Botha and A. Kistner, 1992. Effect of yeast culture supplement on production, rumen fermentation and duodenal nitrogen flow in dairy-cows. J. Dairy Sci., 75:3056.

Hanafy, Y.H., 2008. Nutritional studies on sheep. Ph. D. Thesis, Fac. Agric. Zagazig Univ.

Harrison, G.A., R.W, Hemken, K.A. Dawson, R.J. Harmon and K.B. Barker, 1988. Influence of addition of yeast culture supplement to dies of lactating cows on ruminal fermentation and microbial populations. J. Dairy Sci., 71:2967.

Higgibotham, G.E., C.A.Collar, M.S. Aseltine and D.L. Bath, 1994. Effect of yeast culture and Aspergillus oryzae extract on milk yield in a commercial dairy herd. J. Dairy Sci., 77:343.

Kholif, A.M. and S. M. Kholif, 2008. Effect of Selenium enriched yeast supplementation on the productive performance of lactating buffaloes. Egypt. J. Nutr. and Feeds, 11:187.

Kholif, S. M.and M. M. Khorshed, 2006. Effect of yeast or selenized yeast supplementation to rations on the productive performance of lactating buffaloes. Egypt. J. Nutr. and Feeds, 9:193.

Kumar, U., V.K. Sareen and S. Singh, 1992. A note on the effect of supplementation of yeast culture (Saccharomyces cerevisiae plus growth medium) in the diet of buffaloes on milk yield and composition. J.Anim. Prod. ,55:440.

Kumar. U., V.K. Sareen and S.S. Singh, 1994. Effect of Saccharomyces cerevisiae yeast culture supplement on ruminal metabolism in buffalo calves given a high concentrate diet. Animal Production, 59:209.

Ling, E. R., 1963. A text Book of Dairy Chemistry. Chapman and Hall, Ltd, London.

NRC (1981). Nutrient Requirements of Domestic Animals. Nutrient Requirements of Goats. National Research Council, Washington, D.C.

NewBold, C.J.,R.J. Wallace, X.B. Chen and, F.M. Mclntosh, 1995. Different strains of Saccharomyces cerevisiae differ in their effects on ruminal bacterial numbers in vitro and in sheep. J. Anim. Sci., 73:1811.

Olson, K.C., J.S. Caton, D.R. Kirby and P.L. Norton, 1994. Influence of yeast culture supplementation and advancing season on steers grazing mixed-grass prairie in the northern great Plai: I. Dietary composition, intake and in situ nutrient disappearance. J. Anim. Sci., 72: 2149.

Perntaner , A.,A. Deutz, G. Schlerka and W. Baumgartner, 1991. The somatic cell count in sheep and goat milk. Tierarztl Prax, 19:612. 
Piva, G.,S. Belladonna, G. Fusconi and F. Sicbadi, 1993. Effects of yeast on dairy cow performance, ruminal fermentation, blood components, and milk manufacturing properties. J. Dairy Dci. 76:2717.

Putnam, D.E.,C.G. Schwab, M.T. Socha, N.L. Whiteouse, N.A. Kierstead and B.D. Garthwaite, 1997. Effect of yeast culture in the diets of early lactating dairy cows on ruminal fermentation and passage of nitrogen fractions and amino acids to the small intestine. J. Dairy Sci., 80:374.

SAS Institute, 1994. SAS/STAT user's Guide: Statistics. Ver. 6.04, Fourth Edition SAS Institute Inc, Cary, NC.

Shehata, E.E., F.H. Abd El-Rasoul, M.E. Ahmed, F.F. Abou Ammou and R. ElAhwall, 2004. Effect of feeding a medicinal herb, chamomile flower on production and hygiene of goat milk production. Egypt. J. Nutr. and Feeds, 7:109.

Shehata, E.I, F. H. Abd El- Rasoul, F.F.Abou Ammou, M.E. Ahmed and A. M. Abdel-Gawad, 2007b. Effect of feeding the medicinal herb, chamomil flower, on some productive performance of Egyptian Zaraibi does and their new born kids. Egypt. J. of sheep and Goat Sci., 2:111.

Shehata, E.I., M.E. Ahmed, Faten .F. Abou Ammou, M.A. El-Ashry, A.A.M. Soliman and S.A Tawfik, 2007a. Performance and metabolic profile of Zaraibi goats under different feeding regimes. Egyptian J. Nutrition feeds, 10(2) special Issue: 185

Skorko- Sajko, H., J. Sajko and W. Zalewski, 1993. The effect of yea-sacc ${ }^{1026}$ in the ration of dairy cows on production and composition of milk. J. Animal and Feed Sci., 2:15-167.

Soder, K. J. and L. A. Holden, 1999. Dry mater intake and milk yield and composition of cows fed yeast prepartum and postpartum. J. Dairy Sci. 82:605.

Swartz, D.L., L.D. Muller, G.W. Rogers and G.A. Varga, 1994. Effect of yeast cultures on performance of lactating dairy cows: a field study. J. Dairy Sci 77:3073.

Umberger. S.H., D.R. Notter, K.E. Webb and W.H. McClure, 1989. Evaluation of a Lactobacillus inoculant on feedlot lamb performance. Anim. Sci. Res, Rep. Virginia Agric. Exp. Stat., Virginia Poly., 8:40.

Wiedmeier, R.D.,M.J. Arambel and J.L. Walters, 1987. Effect of yeast culture and Aspergillus oryza fermentation extract on ruminal characteristics and nutrient digestibility. J .Dairy Sci., 70:2063.

Wohlt, J.E., T.T. Corcione and P.K. Zajac, 1998. Effect of yeast on feed intake and performance of cows fed diets based on corn silage during early lactation .J. Dairy Sci., 81:1345.

Wohlt, J.E., A.D. Finkelstein and C.H. Chung, 1991. Yeast culture to improve intake, nutrient digestibility and performance by dairy cattle during early lactation. J. Dairy Sci., 74:1935.

Yousef, H.M.,K.A. El-Masry and A.I. Aboulnaga, 1996. Effect of dried live yeast supplement on haemobiochemical levels \& milk production responses of lactating buffaloes under hot summer conditions in Egypt. Egyptian J. Anim. Prod., 33:11. 
إستجابة الماعز الزرايبى أثناء فترتى الحمل المتأخر وإنتاج اللبن لبعض الإضافات البكتيرية في غذائها

محمد إبراهيم أحمد'، عصام الدين إبراهيم شحاته'، فاتن فهمى أبو عمو'، عبد الجواد مجاهد عبد

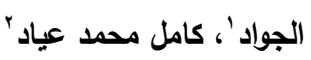

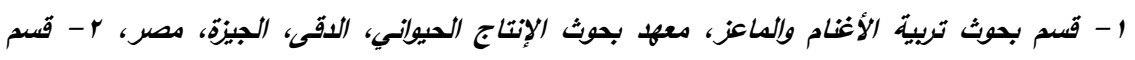

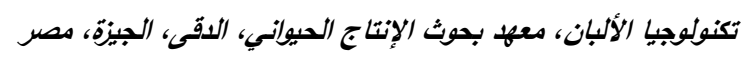

هذا العمل البحثي أجرى على الماعز الزرايبى لدراسة تأثير استخدام أحد الإضافات البكتيرية (اللاكتثر)

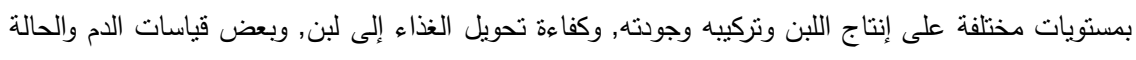

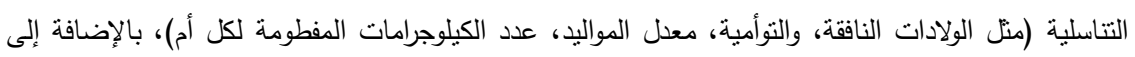

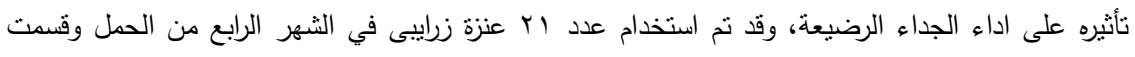

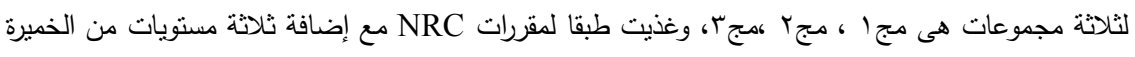
هى صفر ، 1 ، ، جم لكل رأس يوميا للمجموعات الثلاثة على التوالى.

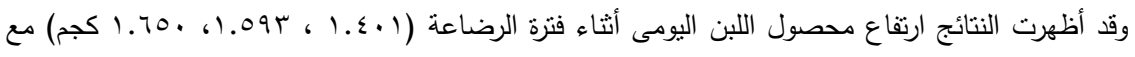

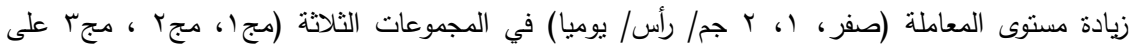

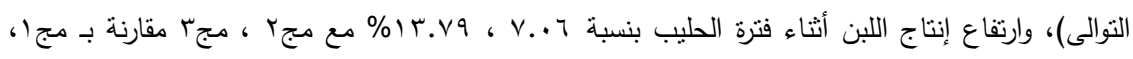
وكانت الاختلافات معنوية أنثاء فترتى التجربة.

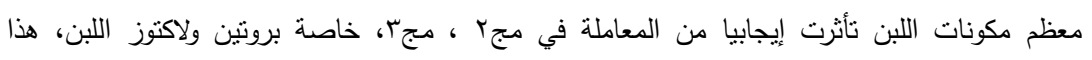

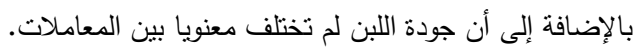

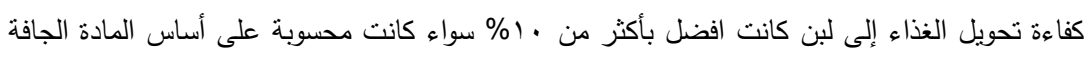

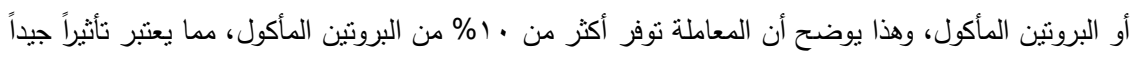

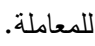

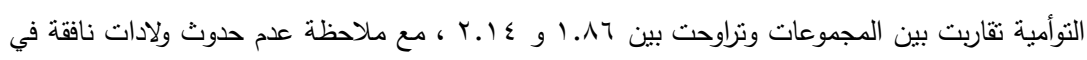

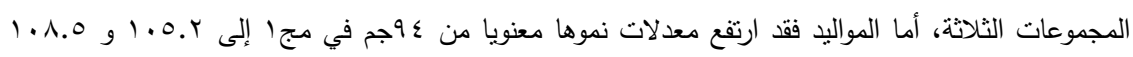

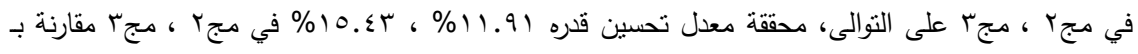

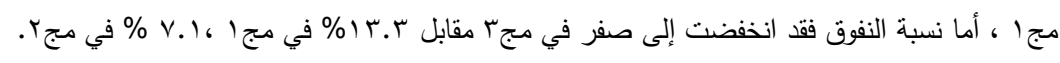

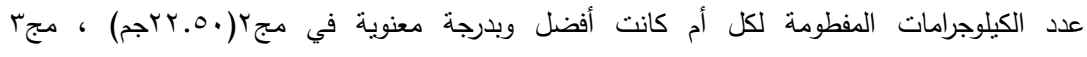

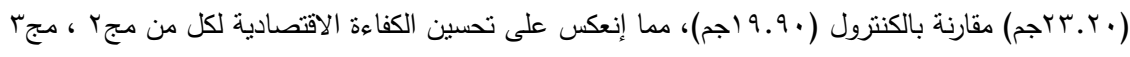

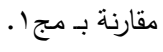


نوضح هذه الدراسة أن استخدام الإضافة البكتيرية (اللاكتشر) في علائق الماعز الزرايبى أثناء الفترة الأخيرة من الحمل وفترة إنتاج اللبن لله تأثير إيجابي على إنتاج اللبن وتركيبه بدون أى تأثنير عكسى على جودة

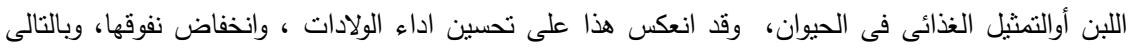
تحسين واضح في إنتاجية الأمهات متمثلا في عدد الكيلوجرامات المفطومة لكل أم سنويا ، مما يحقق منفعة أنساء إقتصادية في قطعان الماعز الزراييى. 